Review

\title{
Implementation of Kinetic and Kinematic Variables in Ergonomic Risk Assessment Using Motion Capture Simulation: A Review
}

\author{
Muhamad Nurul Hisyam Yunus ${ }^{1}$, Mohd Hafiidz Jaafar ${ }^{1,2}, *$, Ahmad Sufril Azlan Mohamed ${ }^{3}$, Nur Zaidi Azraai ${ }^{4}$ \\ and Md. Sohrab Hossain 1,*
}

check for

updates

Citation: Yunus, M.N.H.; Jaafar, M.H.; Mohamed, A.S.A.; Azraai, N.Z Hossain, M.S. Implementation of Kinetic and Kinematic Variables in Ergonomic Risk Assessment Using Motion Capture Simulation: A Review. Int. J. Environ. Res. Public Health 2021, 18, 8342. https:// doi.org/10.3390/ijerph18168342

Academic Editors: Sang Choi, Chao Wang and Shuping Xiong

Received: 23 June 2021

Accepted: 3 August 2021

Published: 6 August 2021

Publisher's Note: MDPI stays neutral with regard to jurisdictional claims in published maps and institutional affiliations.

Copyright: (c) 2021 by the authors. Licensee MDPI, Basel, Switzerland. This article is an open access article distributed under the terms and conditions of the Creative Commons Attribution (CC BY) license (https:// creativecommons.org/licenses/by/ $4.0 /)$.
1 School of Industrial Technology, Universiti Sains Malaysia, USM, Penang 11800, Malaysia; hisyam_yunus@student.usm.my

2 National Poison Centre, Universiti Sains Malaysia, USM, Penang 11800, Malaysia

3 School of Computer Sciences, Universiti Sains Malaysia, USM, Penang 11800, Malaysia; sufril@usm.my

4 School of the Arts, Universiti Sains Malaysia, USM, Penang 11800, Malaysia; nurzaidi@usm.my

* Correspondence: mhafiidz@usm.my (M.H.J.); sohrab@usm.my (M.S.H.)

\begin{abstract}
Work-related musculoskeletal disorders (WMSDs) are among the most common disorders in any work sector and industry. Ergonomic risk assessment can reduce the risk of WMSDs. Motion capture that can provide accurate and real-time quantitative data has been widely used as a tool for ergonomic risk assessment. However, most ergonomic risk assessments that use motion capture still depend on the traditional ergonomic risk assessment method, focusing on qualitative data. Therefore, this article aims to provide a view on the ergonomic risk assessment and apply current motion capture technology to understand classical mechanics of physics that include velocity, acceleration, force, and momentum in ergonomic risk assessment. This review suggests that using motion capture technologies with kinetic and kinematic variables, such as velocity, acceleration, and force, can help avoid inconsistency and develop more reliable results in ergonomic risk assessment. Most studies related to the physical measurement conducted with motion capture prefer to use non-optical motion capture because it is a low-cost system and simple experimental setup. However, the present review reveals that optical motion capture can provide more accurate data.
\end{abstract}

Keywords: kinetic variables; kinematic variables; ergonomic risk assessment; motion capture

\section{Introduction}

All job sectors and industry sectors have various risks that can cause accidents and injuries. The study on the safety and health of industrial activities is critical to providing a better atmosphere in the workplace. Figure 1 shows five main categories of hazards related to the workplace according to occupational safety and health standards.

Ergonomics is the study to design workstations, work practices, and workflows for the worker in order to reduce risk factors such as sprains, strains, and cumulative trauma disorders [1]. The objective of an ergonomics assessment is to determine the level of risk for work-related tasks [1]. Unergonomic working conditions can contribute to discomfort and fatigue, leading to muscle, tendon, ligament, nerve, and blood vessel injury. This group of injuries is known as musculoskeletal disorders [2]. Work-related musculoskeletal disorder is the most common injury in the workplace [3]. Common risk factors for workrelated musculoskeletal disorders are task frequency, manual material handling, load weight, awkward posture, vibration, flexion angle, and extension angle [4-6]. This disorder will cause pain, injury, illness, negative economic impact, reduced work performance, and decreased productivity [2,7]. Figure 2 shows the number of workers affected by diseases reported by the group in Europe from 2013 to 2015 [8]. It was also observed that musculoskeletal disorder constitutes a major work health issue compared to other 
work-related diseases. Therefore, it is crucial to design an ergonomic workstation to reduce musculoskeletal disorder.

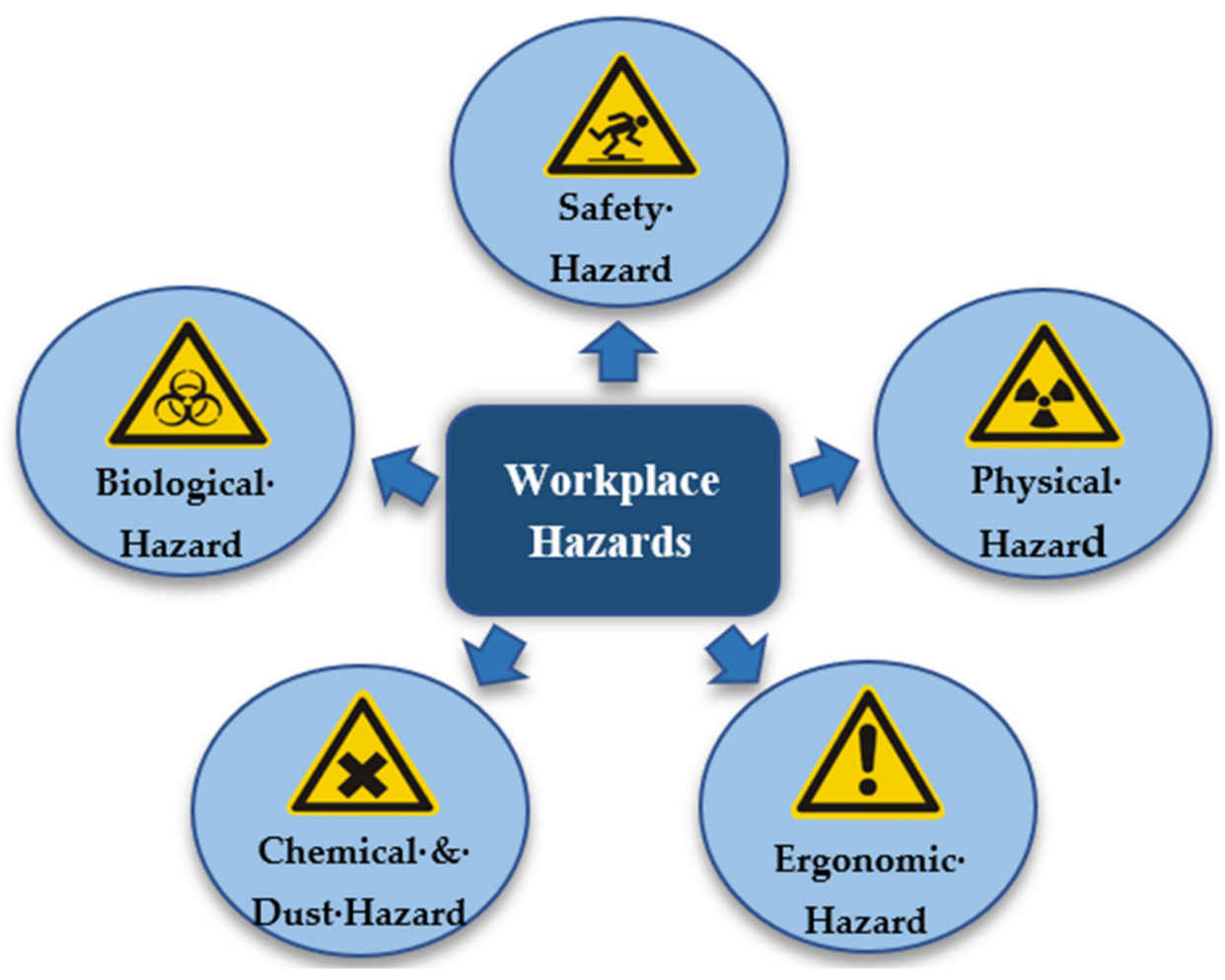

Figure 1. The five main hazards involve in workplaces.

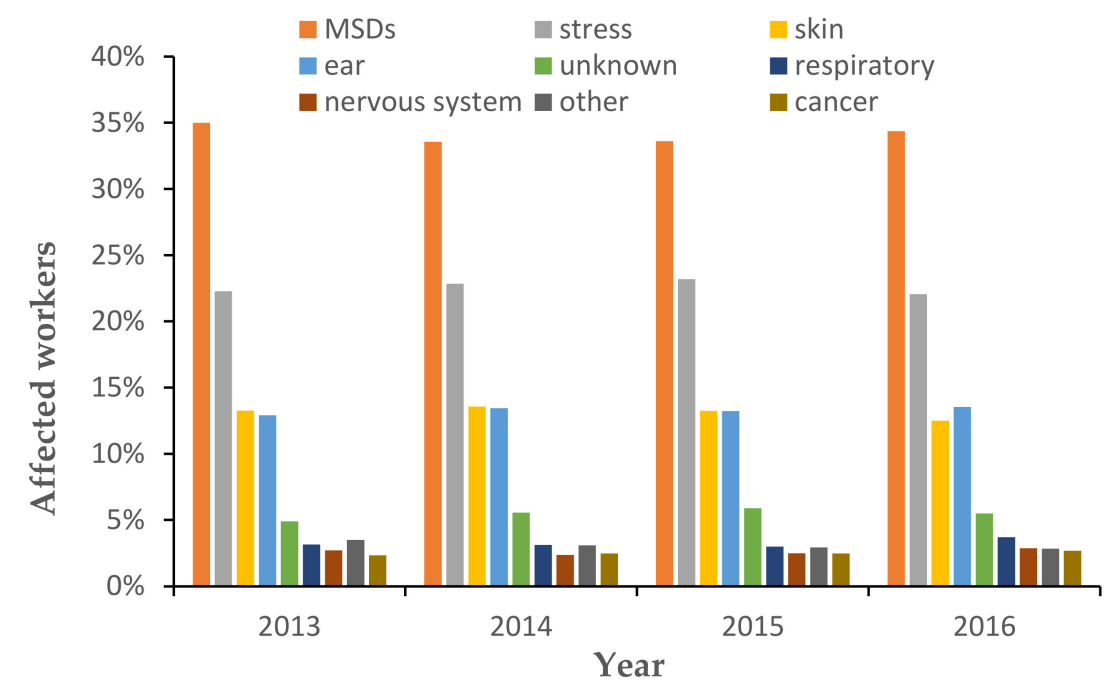

Figure 2. Number of workers affected by diseases reported by the group in Europe [8].

Rapid Upper Limb Assessment (RULA), Rapid Entire Body Assessment (REBA), Agricultural Upper-Limb assessment (AULA), and Ovako Working Posture Analysis System (OWAS) are among many ergonomic assessment tools to evaluate ergonomic risk factors $[7,9]$. These tools have been used widely in the industrial sector. Most ergonomic risk assessment tools focus on the qualitative view to describe the risk level of motion and posture. The aim of this review is to assess the technology of motion capture that is suitable to evaluate ergonomic risk assessment in various industries. Motion capture technology includes optical and non-optical motion capture. The suggestions of this review would provide a view on the ergonomic risk assessment method and apply the current 
technology motion capture with the understanding of classical mechanics of physics that include velocity, acceleration, force, and momentum in ergonomic risk assessment.

\section{Motion Capture Simulation}

The standard way to assess ergonomic risk is by using motion capture technology [10-14]. Table 1 shows the advantage and limitations of motion capture systems in determining ergonomic risk assessment. Motion capture is the process of tracking the motion of a subject digitally. An ergonomic risk assessment using motion capture comes under the category of direct measurement methods, which use depth sensors to capture human motion [10]. These methods are believed to be the most accurate for providing reliable data to evaluate the ergonomic risk $[5,15]$. Motion capture is a powerful tool that can be used in many applications for human motion analysis [16]. Motion capture can provide data consisting of a skeleton diagram, body angle deviation, body velocity, and body acceleration $[14,17,18]$. Several researchers have exploited motion capture technology to evaluate recent ergonomic risk assessment tools such as RULA and REBA [14,18].

Table 1. Advantages and limitations of motion capture systems in determining ergonomic risk assessment.

\begin{tabular}{|c|c|c|c|c|c|c|c|c|}
\hline $\begin{array}{l}\text { Motion } \\
\text { Capture }\end{array}$ & Type & & Data & & Advantage & & Disadvantage & References \\
\hline \multirow[b]{2}{*}{ Optical } & Markerless & $\begin{array}{l}- \\
- \\
-\end{array}$ & $\begin{array}{l}\text { Time taken } \\
\text { Displacement } \\
\text { Body Velocity } \\
\text { Body Acceleration }\end{array}$ & $\begin{array}{l}- \\
- \\
-\end{array}$ & $\begin{array}{l}\text { Low cost } \\
\text { Portable } \\
\text { Real-time result } \\
\text { Simple start-up }\end{array}$ & - & $\begin{array}{l}\text { Less accurate } \\
\text { Magnetic } \\
\text { interference noise }\end{array}$ & [17-21] \\
\hline & Marker Based & $\begin{array}{l}- \\
- \\
- \\
- \\
-\end{array}$ & $\begin{array}{l}\text { Time taken } \\
\text { Displacement } \\
\text { Body Velocity } \\
\text { Body acceleration } \\
\text { Body angle deviation } \\
\text { Body posture }\end{array}$ & $\begin{array}{l}- \\
- \\
- \\
-\end{array}$ & $\begin{array}{l}\text { Accurate } \\
\text { Fast } \\
\text { Automatic tool } \\
\text { analysis } \\
\text { Real time result }\end{array}$ & $\begin{array}{l}- \\
- \\
-\end{array}$ & $\begin{array}{l}\text { Costly } \\
\text { Complex tool } \\
\text { Not Portable }\end{array}$ & [22-25] \\
\hline \multirow{4}{*}{ Non-Optical } & Pressure sensor & - & $\begin{array}{l}\text { Pressure } \\
\text { Force }\end{array}$ & - & $\begin{array}{l}\text { Low cost } \\
\text { Simple } \\
\text { experiment } \\
\text { set-up }\end{array}$ & - & $\begin{array}{l}\text { Limited to } \\
\text { relatively low } \\
\text { pressure }\end{array}$ & {$[26,27]$} \\
\hline & Inertial & $\begin{array}{l}- \\
-\end{array}$ & $\begin{array}{l}\text { Electrical pulse } \\
\text { (Muscle activity) } \\
\text { Body acceleration } \\
\text { Body velocity }\end{array}$ & - & $\begin{array}{l}\text { Potable } \\
\text { Low cost }\end{array}$ & - & $\begin{array}{l}\text { Less accurate } \\
\text { Can cause } \\
\text { discomfort to } \\
\text { the subject } \\
\text { Magnetic } \\
\text { interference noise }\end{array}$ & [28-31] \\
\hline & Force plate & - & Force & - & Portable & & & {$[32,33]$} \\
\hline & Mechanical & $\begin{array}{l}- \\
- \\
-\end{array}$ & $\begin{array}{l}\text { Time taken } \\
\text { Body velocity } \\
\text { Body acceleration } \\
\text { Body posture }\end{array}$ & - & High Accuracy & - & $\begin{array}{l}\text { Cause discomfort } \\
\text { to subject } \\
\text { Heavy }\end{array}$ & {$[34]$} \\
\hline
\end{tabular}

The workflow for an ergonomic risk assessment using motion capture technology is shown in Figure 3. The use of motion capture simulation in assessing ergonomic risk is a remarkable improvement because this simulation can provide detailed and accurate human motion data [35]. However, a recent study that used motion capture technologies in ergonomic risk assessment is still based on the ergonomic assessment methods $[23,36]$. It would be helpful if the data from motion capture technologies such as body velocity and body acceleration were optimally used to analyze human motion. The added value of body velocity and body acceleration can contribute a more reliable result in ergonomic risk assessment. Inconsistency and biased judgment can be avoided with the use of accurate quantitative data on the evaluation from motion capture simulation. The assessment can also be carried out without the presence of an advanced ergonomist or physiologist. There- 
fore, there is a need to develop a complete method that uses a quantitative technique for better understanding the ergonomic risk factor and developing preventative steps [16,37]. Unfortunately, high accuracy motion capture systems, such as the Vicon tracking system, are not portable and are costly [37]. However, low-cost motion capture systems, such as Kinect, cannot provide reliable and accurate data for biomechanical analysis [38].

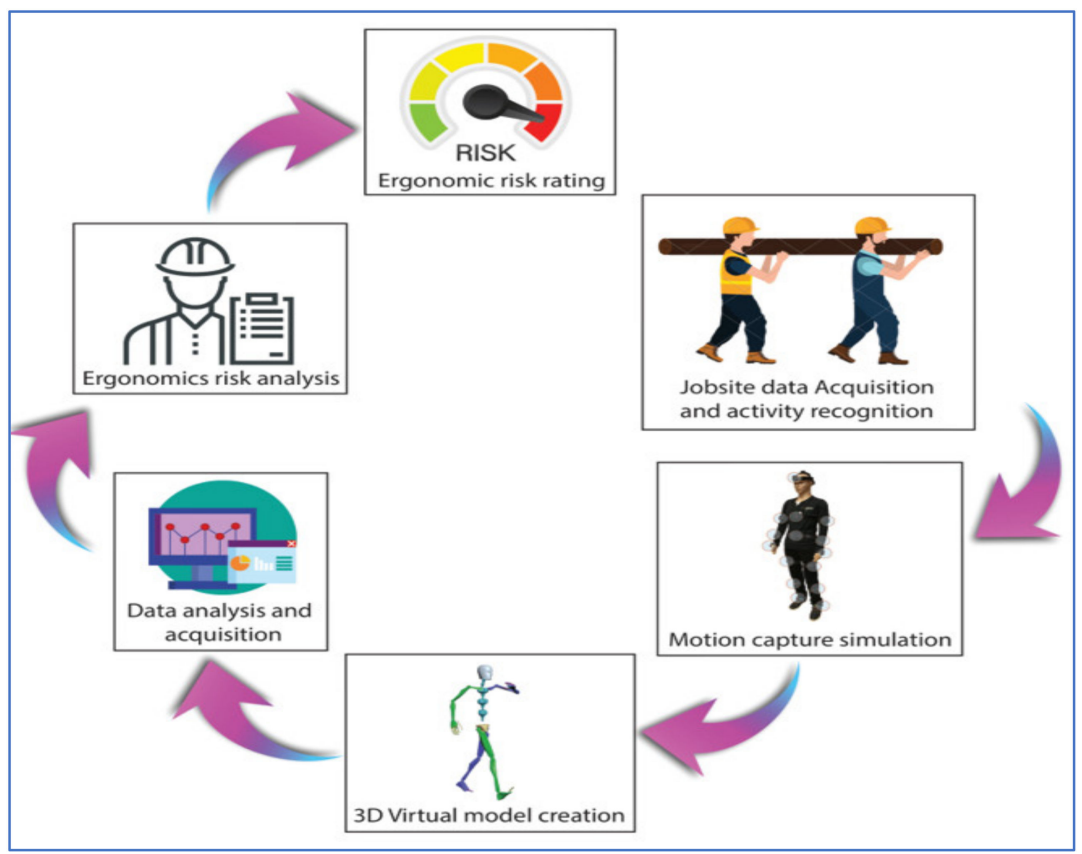

Figure 3. Workflow for the ergonomics risk assessment using motion capture technology.

Motion capture can be categorized into optical and non-optical methods [31]. Figure 4 shows the difference between optical and non-optical motion capture simulation for ergonomic risk assessment $[10,31,39]$. An optical motion capture system is a camera-based method, while the non-optical motion capture system is tracking motion from the relative position of different segments [31]. However, optical motion capture is suitable to assess aggressive and dynamic human activities [10,40]. This is because optical motion capture uses cameras, and the number of cameras and the frame rate can, therefore, be adjusted based on the motion capture requirements [10]. Currently, there are two types of optical motion capture used for biomechanical studies, which are marker-based and markerless motion capture $[39,40]$. Conversely, non-optical motion capture is tracking the motion without a visual field. It enables assessments to be performed in areas where the visibility is impaired or impossible [10]. A well-known non-optical motion capture system is an inertial measurement unit (IMU) that uses wearable sensors such as accelerometers, gyroscopes, and magnetometers on the body to capture the motion $[15,28,31]$. Motion capture is beneficial in a number of research fields related to biomechanics, but the accuracy of the system must be assured [41]. Both motion capture systems have their advantages and disadvantages based on the purpose of their use. Humadi et al. [42] determined the reliability and accuracy of non-optical and optical motion capture technologies using a wearable technology and a markerless optical technology, respectively, for different manual materials handling tasks. The study reported that the non-optical motion capture technology is more suitable than markerless optical technology in ergonomics risk assessment. Brunner et al. [43] determined ergonomic risk assessment in occupational practice using marker-based (Vicon Bonita) and markerless (Microsoft Kinect V2) optical motion capture systems, wherein the captured working postures were evaluated by analyzing the angles of different body segments. The study reported that markerless motion capture measured greater values than the marker-based motion capture in estimating potential health risk while conducting postural ergonomic risk assessments. However, Fletcher et al. [10] evaluated the ergonomic 
risk assessment of manufacturing work using the inertial non-optical motion capture. Their study reported that the non-optical motion capture method could better record motion data suitable for postural analysis from within an occluded workplace.

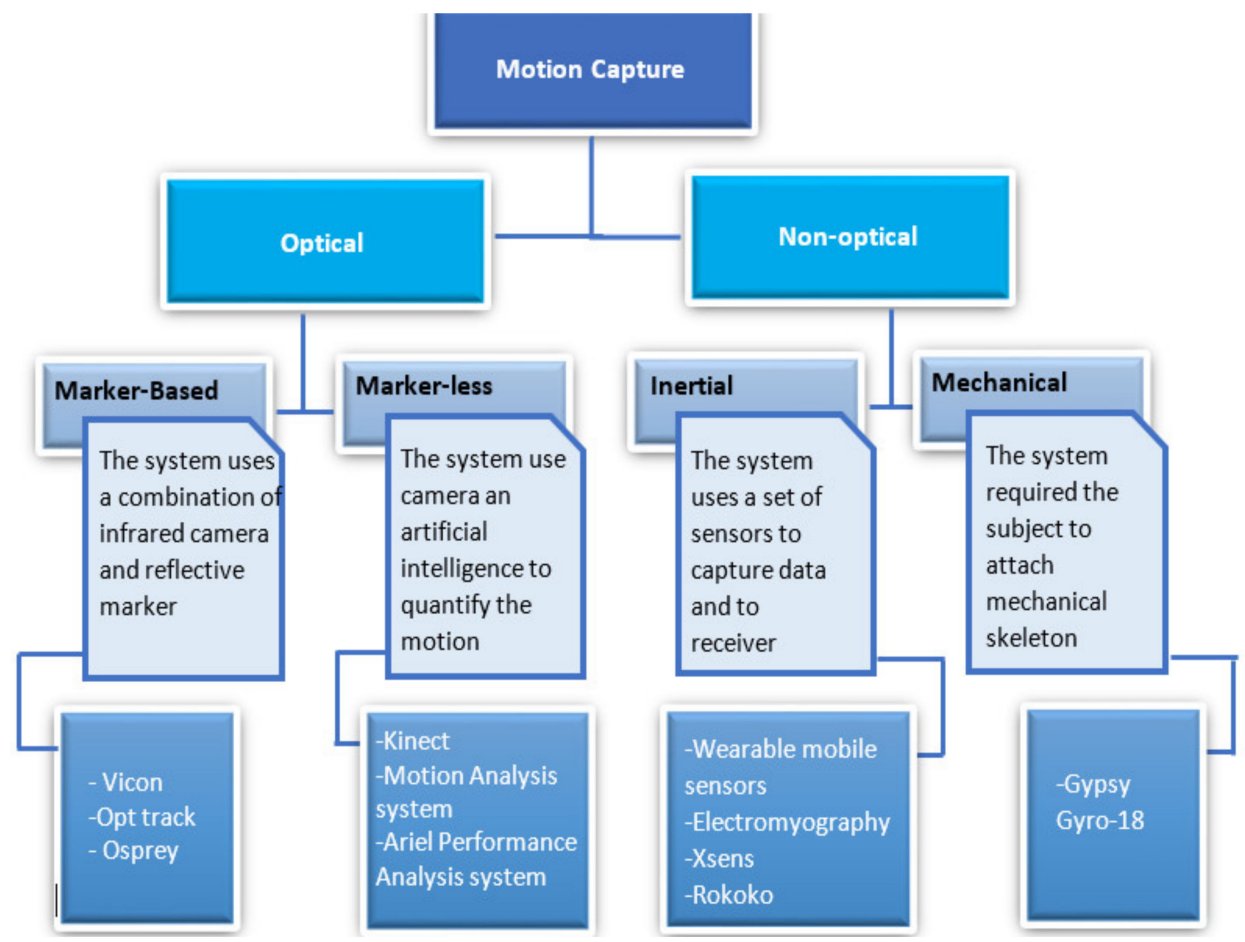

Figure 4. Optical and Non-optical motion capture simulation for ergonomics risk assessment.

\section{Ergonomic Risk Assessment}

Ergonomic risk assessment is an important task in evaluating risk activities in the workplace [1,44]. Ergonomic risk assessment supports provision of a healthy work environment and the design of a workplace for optimum work performance [1]. Table 2 shows the advantages of ergonomic risk assessment in a work sector.

Table 2. The advantage of ergonomics risk assessment methods.

\begin{tabular}{|c|c|c|c|}
\hline $\begin{array}{c}\text { Ergonomic } \\
\text { Assessment Method }\end{array}$ & Tools & Advantage & References \\
\hline Self-report & $\begin{array}{ll}\text { - } & \text { Nordic Musculoskeletal } \\
\text { Questionnaire (NMQ) } \\
\text { - } \quad \text { Cornell Musculoskeletal Discomfort } \\
\text { Questionnaire (CMDQ) }\end{array}$ & $\begin{array}{ll}\text { - } & \text { No technical equipment needed } \\
\text { - } & \text { Inexpensive } \\
& \text { Suitable for large scale assessment }\end{array}$ & [45-48] \\
\hline Observational & $\begin{array}{ll}\text { - } & \text { Rapid upper-limb assessment (RULA) } \\
\text { - } & \text { Rapid entire body assessment (REBA) } \\
\text { - } & \text { Quick exposure checklist (QEC) } \\
\text { - } & \text { Strain index }\end{array}$ & $\begin{array}{l}\text { - } \quad \text { Easy to use } \\
\text { - } \quad \text { Quick assessment } \\
\text { - } \quad \text { Cover whole body posture }\end{array}$ & [49-53] \\
\hline Direct measurement & $\begin{array}{ll}\text { - } & \text { Lumbar Motion Monitor (LMM) } \\
\text { - } & \text { Force sensor } \\
\text { - } & \text { Electromyography }\end{array}$ & $\begin{array}{ll}\text { - } & \text { High accuracy } \\
\text { - } & \text { Able to quantify quantitative data } \\
\text { - } & \text { Suitable for research context }\end{array}$ & {$[29,54-56]$} \\
\hline
\end{tabular}

The physical approach is the most common method that ergonomists have used in ergonomic risk assessment, and it can be divided into self-report, systematic observational, and direct measurement $[7,54]$. Each method has its own advantages and disadvantages. This present study reviewed the three ergonomic risk assessment methods involved in 
the physical approach. The self-report method uses a set of questionnaires and surveys to quantify and assess the discomfort severity experienced by the worker. This method is useful to study the experience of workers as the discomfort cannot be observed and measured directly [52]. Most musculoskeletal disorders begin with discomfort and stress experienced by workers. The Nordic Musculoskeletal Questionnaire and Cornell Musculoskeletal Discomfort Questionnaire are examples of tools based on this method $[45,46]$. The advantage of this method is that no technical equipment is needed, making it relatively inexpensive and easy, with the data and input directly from the subject [47]. This approach is also suitable to be conducted on a large scale of issues [48]. In a recent study, Huang et al. [44] developed a method for assessing WMSDs in the workspace using a wearable inertial sensor-based automated system to overcome the limitations of traditional WMSDs risk assessment methods. The study reported that the wearable inertial sensor-based automated system has the potential to be used for WMSDs risk assessments of workers when performing tasks in a workspace. Kim et al. [57] employed a new open-source human post estimation technology (OpenPose) for computing RULA/REBA scores and joint angles to determine ergonomic postural assessment. It was found that OpenPose has the potential to be utilized as a promising technology to determine semi-automatic ergonomic postural assessments and to measure joint angles in the non-ideal condition of a real workspace.

Observational methods provide ergonomists with postural evaluation tools to assess the ergonomic risk. This method can be used to analyze various occupational tasks and the workplace. Rapid Upper Limb Assessment and Rapid Entire Body Assessment are the preeminent and easiest tools for rapid ergonomic risk assessment in observational methods to evaluate work-posture $[49,58]$. RULA provides the level of postural load for the upper limb and REBA for the entire body [53,59]. Other ergonomic assessments, such as the Quick Exposure Checklist and the Strain Index, are also used for ergonomic risk assessment $[50,55]$. The advantages of these tools are that they can be conducted by inexperienced users as these tools are easy to learn and quick to use [51,52]. These ergonomic risk assessment tools also give an immediate result and mainly cover whole body posture to adequately assess work-related musculoskeletal disorder risk $[7,53]$.

Direct measurement methods have a similar objective to observational methods but with different basic approaches [29]. This method is an instrument-based method that collects the information through the sensor attached to the body of the subject [54]. Generally, the direct measurement method is preferred for the research context [52]. This approach requires software, sensor, and data logger to obtain the quantitative data, for example, Lumbar Motion Monitor (LMM), force sensor, and electromyography $[55,56]$. The advantage of this method is it offers high accuracy of posture assessment for musculoskeletal studies [52]. This method is also useful to quantify the quantitative data, such as force exerted, which cannot be assessed from observation. [22].

Despite the advantages listed, some researchers still raised an issue about the frailty and the limitations among current ergonomic risk assessment methods [56,60-62]. The question about accuracy and consistency in ergonomic risk assessment methods is often discussed academically. Studies on the validity and reliability of the Nordic Musculoskeletal Questionnaire have found that there is very little information related to psychometric properties [47,48]. Current ergonomic risk assessment tools only focus on the posture of the movement without analyzing the motion of the movement. RULA, REBA, and many other ergonomic risk assessment methods rely upon direct observation [63]. This method of ergonomic risk assessment needs a certified professional ergonomist involved to evaluate the assessment, and potentially the rate of ergonomic risk is biased due to subjective judgment $[64,65]$. The assessment result among all observational ergonomic risk assessment methods is inconsistent because of differing basic approaches [65]. Most ergonomic assessments claimed that the method could include the variable of force to evaluate the risk from the motion. The fact is force means the product of acceleration and mass or load. Unfortunately, the body acceleration is neglected during the assessment. 


\section{Kinetic and Kinematic Variable}

To assess the ergonomic risk from analyzing the motion, the classical mechanics of physics approach is needed. There are three fundamental laws in classical mechanics, such as [66,67]:

(a) Newton's first law: object will remain at rest or constant velocity unless an external force acts on it;

(b) Newton's second law: the force is equal to the product of mass and acceleration; and

(c) Newton's third law: when a body exerts a force on another body, the body will have equal force with the first body.

This shows that if force is used to describe the motion, then body velocity and body acceleration also need to be discussed because velocity, acceleration, and force correlate. Velocity is the displacement over time, acceleration is the derivative of velocity, and force is the product of the derivative of velocity and mass. Equations (1)-(3) describe the relation of velocity, acceleration, and force.

$$
\begin{gathered}
v(t)=\frac{d x}{d t} \\
a(t)=\frac{d^{2} x}{d t^{2}}=\frac{v(t)}{d t} \\
f=m \frac{v(t)}{d t}=m a(t)
\end{gathered}
$$

where $v(t)$ is velocity, $a(t)$ is acceleration, $f$ is force, $d x$ is displacement, $d t$ is the time taken, and $m$ is mass. Research using the electromyography approach has shown that any muscle activity, such as during lifting, correlates with the physical measure consisting of velocity, acceleration, and force [68]. This indicates that input data related to physical measures are necessary for evaluating the ergonomic risk assessment. Therefore, using quantitative data in the ergonomic risk assessment is important to reduce the risk of musculoskeletal disorder [17]. With accessibility to technology such as motion capture, which can provide data on velocity, acceleration, and force, assessing ergonomic risk by evaluating this variable from body motion is now possible. Table 3 summarizes the recent

\begin{tabular}{|c|c|c|c|c|}
\hline Data Input & $\begin{array}{c}\text { Motion } \\
\text { Capture Type }\end{array}$ & System & Research Scope/Finding & References \\
\hline \multirow{3}{*}{ Velocity } & \multirow{3}{*}{ Optical } & Microsoft Kinect V2 & $\begin{array}{l}\text { Evaluate the cycle time of worker in the } \\
\text { set-up workstation }\end{array}$ & [18] \\
\hline & & Kinect based & $\begin{array}{l}\text { Compare the martial art performance } \\
\text { (Silat) between novice and } \\
\text { experienced performer }\end{array}$ & [19] \\
\hline & & Optitrack & $\begin{array}{l}\text { Evaluate the kinematic data of shoulder } \\
\text { and elbow during walking with } \\
\text { different pace }\end{array}$ & [22] \\
\hline \multirow{2}{*}{ Acceleration } & \multirow{2}{*}{ Optical } & Ipi soft Motion capture & $\begin{array}{l}\text { The maximum back compressive force } \\
\text { produced during high acceleration and } \\
\text { angle of trunk flexion }\end{array}$ & [17] \\
\hline & & $\begin{array}{l}\text { Northern Digital } \\
\text { Optotrak } 3020 \text { motion } \\
\text { tracking system }\end{array}$ & $\begin{array}{l}\text { Perceived heaviness is the function of } \\
\text { ratio of muscle activity to acceleration }\end{array}$ & [30] \\
\hline
\end{tabular}
studies related to the kinematic and kinematic variable by using motion capture.

Table 3. Summary of recent studies related to kinetic and kinematic variables by using motion capture. 
Table 3. Cont.

\begin{tabular}{|c|c|c|c|c|}
\hline Data Input & $\begin{array}{c}\text { Motion } \\
\text { Capture Type }\end{array}$ & System & Research Scope/Finding & References \\
\hline \multirow{4}{*}{ Acceleration } & \multirow{4}{*}{ Non-Optical } & Wearable accelerometer & $\begin{array}{l}\text { Predict the angle of deviation for shoulder } \\
\text { and trunk flexion using the } \\
\text { angular acceleration }\end{array}$ & [28] \\
\hline & & Wearable accelerometer & $\begin{array}{l}\text { Proposed low-cost wearable inertial } \\
\text { sensor to track the upper body movement }\end{array}$ & [69] \\
\hline & & Wearable accelerometer & $\begin{array}{l}\text { The proposed wearable sensor is } \\
\text { potentially acceptable for slow tasks to } \\
\text { predict the trunk flexion }\end{array}$ & [64] \\
\hline & & $\begin{array}{l}\text { OpenGo system } \\
\text { (Moticon) }\end{array}$ & $\begin{array}{l}\text { Evaluate the risk of overexertion based on } \\
\text { acceleration and pressure data }\end{array}$ & [26] \\
\hline \multirow{5}{*}{ Force } & Optical & $\begin{array}{c}\text { Ariel performance } \\
\text { analysis system (APAS) }\end{array}$ & $\begin{array}{l}\text { The musculoskeletal injury happened } \\
\text { when normal forces are exerted to } \\
\text { abnormally weak tissues or when high } \\
\text { forces are exerted to normal tissues }\end{array}$ & [20] \\
\hline & \multirow{4}{*}{ Non-Optical } & Electromyogram (EMG) & $\begin{array}{l}\text { The higher the trunk flexion angle, the } \\
\text { higher the compression force }\end{array}$ & [70] \\
\hline & & Electromyogram (EMG) & $\begin{array}{c}\text { Anterior deltoid and upper trapezius are } \\
\text { under high demand during load transfer } \\
\text { tasks for people with lower back pain and } \\
\text { spinal cord injury }\end{array}$ & {$[71]$} \\
\hline & & $\begin{array}{l}\text { Baltimore therapeutic } \\
\text { equipment (BTE) }\end{array}$ & $\begin{array}{l}\text { Data collected during the study using } \\
\text { accelerometer sensor has a correlation } \\
\text { with force applied by muscle }\end{array}$ & [29] \\
\hline & & Force plate & $\begin{array}{l}\text { Calculate the ground reaction forces and } \\
\text { moment from the walking task with } \\
\text { different pace }\end{array}$ & [41] \\
\hline
\end{tabular}

\subsection{Velocity and Acceleration}

The main factor contributing to musculoskeletal disorder is the frequency, magnitude, and time taken of musculoskeletal load exerted on the join of the subject [17]. Velocity and acceleration are the correct terms to discuss work time is taken, pace, magnitude, and frequency. The difference between speed and velocity is that velocity consists of magnitude and direction, while speed is only a magnitude. Data for body velocity and acceleration can evaluate the pace of the movement [22]. Reducing processing time is an appropriate solution to cut costs. This causes the worker to move rapidly or work at a high pace [34]. Doing a job at a fast pace does not mean it is right, but it can turn out to be a risk factor. The previous study has also proved that a slow working pace is more hazardous than a fast-working pace [72]. This shows that it is essential to do work at an optimal working pace. The data for body velocity and acceleration can be used to compare the work pace of experienced and novice workers [19]. This method can be a benchmark to develop the optimal work pace. Therefore, to determine the optimal work pace in manual handling tasks, occupational risk factors, and work position standards that follow the ergonomic intervention are very important [2]. They can increase productivity and reduce the risk of musculoskeletal injury.

Recent ergonomic risk assessment tools, such as REBA and RULA, only include load to evaluate the body posture. Working pace can affect muscle temporal recruitment pattern while lifting, such as triceps, biceps, deltoid, and trapezius, but load or weight during lifting did not affect temporal muscle recruitment pattern [73]. Waddell and Amazeen [30] found that the perceived heaviness during lifting tasks correlates with muscle activity and lifting speed. The lifting speed has also been found to be affected by peak compressive 
force [10]. Medium pace during the initial lifting is very beneficial to avoid jerky or awkward movement and produce less back compressive force [72]. Hence, to assess the ergonomic risk of tasks that deal with the load, the body velocity and acceleration also need to be considered to achieve reliable results.

Other than evaluating the work pace, data for velocity and acceleration from the motion capture can be used to improve the workstation layout [18]. Motion capture can map the movement of the subject with detail on the velocity and displacement $[18,19,74]$. This can help to reduce unnecessary action during walking, for example walking throughout the working station. Other than for ergonomic risk assessment, this data can be used to compare the movement of experienced workers and novice workers, which can improve work performance [19]. This method can also verify the effect of environmental changes to the behavior of the subject in terms of their work performance and work [23].

The data for initial acceleration from the body motion have a high correlation with work-related musculoskeletal disorder [34]. From Equation (2), velocity and acceleration input data are closely related to each other. When the body velocity increases, the body is accelerating; while the body velocity decreases, it indicates that the body is decelerating. In another case, if the body has a constant velocity, it means the body acceleration is zero. The movement shows much acceleration, and deceleration indicates that the movement is vigorous and dynamic. The data for body acceleration can also be used to determine the range of motion or the angle of deviation [28]. Angle deviation is the degree of bend from the neutral posture where all body parts are in a state of minimal effort, physical stress on bones, muscles, nerves, or tendons [28]. When the body velocity is increasing rapidly, which means that acceleration exists, the body angle deviation and the range of motion are higher $[17,22]$. This shows that mathematically body acceleration could predict the trunk and shoulder flexion with an accurate angle [28]. Inertial motion capture systems such as wearable accelerometers use this method to predict the angle of deviation $[28,31,67]$. However, the accuracy is low for dynamic movement [31,62]. Equation (8) describes the formula for predicting the angle of trunk and shoulder flexion [28].

$$
P_{x}=\cos ^{-1}\left(\frac{P_{x \_a c c \_m a x}-P_{90 \_} a c c \_ \text {max }}{P_{1 \_a c c \_m a c}-P_{90 \_} a c c \_ \text {max }}\right)
$$

where $P_{x}$ is the total angle of deviation for selected postures, $P_{x \_} a c c_{-}$max is the acceleration for the selected postures, $P_{1 \_a c c}$ max is the initial acceleration for the selected posture, and $P_{90 \_} a c c \_m a x$ is the acceleration for a $90^{\circ}$ selected posture. The acceleration for initial and $90^{\circ}$ is pre-recorded before the actual observation with the same work pace. Generally, from the ergonomic risk assessment perspective, the body angle deviation determines the awkward posture [28]. Awkward posture and overexertion are factors that can contribute to work-related musculoskeletal disorder [26,75]. However, previous methods of ergonomic risk assessment did not discuss this matter in detail [26]. In physical terms, they describe inertia awkwardly. In addition, it uses data on body acceleration to describe inertia. Awkward posture happens when the acceleration is high. Therefore, the body acceleration from the movement must be lower to achieve an ergonomic movement.

The body velocity and acceleration data can be obtained through optical motion capture or non-optical motion capture such as an accelerometer $[15,64,67]$. Equations (4)-(6) describes the calculation for velocity collected through optical motion capture if the frame rate is set to 9 [56].

$$
\begin{aligned}
& v\left(y_{i}\right)=\frac{(F R) \times(y(i+4)-y(i-4))}{8} \\
& v\left(z_{i}\right)=\frac{(F R) \times(z(i+4)-z(i-4))}{8}
\end{aligned}
$$

where $F R$ is the frame rate, and $i$ is the number of frames. The resultant velocity, $R_{v}$ can be determined as:

$$
R_{v}=\sqrt{v\left(x_{i}\right)^{2}+v\left(y_{i}\right)^{2}+v\left(z_{i}\right)^{2}}
$$


The below equations describes the calculation for body acceleration, which are the derivative from Equations (4)-(6) [62].

$$
\begin{aligned}
& a\left(x_{i}\right)=\frac{d}{d t} v\left(x_{i}\right)=\frac{F R^{2} \times(x(i+4)-2 x(i)+x(i-4))}{16} \\
& a\left(y_{i}\right)=\frac{d}{d t} v\left(y_{i}\right)=\frac{F R^{2} \times(y(i+4)-2 y(i)+y(i-4))}{16} \\
& a\left(z_{i}\right)=\frac{d}{d t} v\left(z_{i}\right)=\frac{F R^{2} \times(z(i+4)-2 z(i)+z(i-4))}{16}
\end{aligned}
$$

The resultant acceleration can be determined as:

$$
R_{a}=\sqrt{a\left(x_{i}\right)^{2}+a\left(y_{i}\right)^{2}+a\left(z_{i}\right)^{2}}
$$

\subsection{Force}

Body force is generated by the acceleration of the body part during the movement [10]. From Equation (3), the data for body acceleration can determine the force exerted by the body during the movement. This indicates that the force applied by muscle correlates with body acceleration [29]. Direct measurement of the force exerted during physical tasks can effectively reduce the risk of work-related musculoskeletal disorder $[17,20,29]$. A musculoskeletal disorder can occur when a normal force is exerted on weak tissues or when high force is exerted on normal tissues [20]. When a body holds an object, muscle activity is required to resist gravity force, which shows the correlation of muscle activity with force during muscle flexion and contraction [30]. During manual handling tasks such as lifting and carrying the load, the magnitude of the force exerted on the muscle's joint directly impacts the magnitude of joint reaction [20]. Thus, the evaluation of the body forces during the movement is important in determining the ergonomic risk.

There are many ways to predict the force exerted by the body. The body force can be calculated using Baltimore therapeutic equipment to simulate work activities related to pushing and pulling [29]. The data output from this simulator is in watt $P$. The approximation of body net force exerted is achieved by using the equation below [29].

$$
F=\frac{P \times t}{d}
$$

where $P$ is watt in $\mathrm{kgm}^{2} / \mathrm{s}^{-3}, t$ is time in second (s), and $d$ is displacement in meter $(\mathrm{m})$. In this study, the time and displacement were measured through observation. From Equation (12), it can be assessed that time over displacement is the data for body velocity. Velocity can be measured using optical motion capture that gives more accurate data than when measured through direct observation. Additionally, another approach to predict body force is by using an electromyogram (EMG), a non-optical motion capture system, where the force predicted by electromyography is considered as the force exerted by muscle or muscle activity $[23,66,68]$. This method requires the subject to wear a wired sensor directly to their skin, which is somewhat difficult and intrusive [63]. The validity of the predicted force obtained from this method is still in question. This is because the force is the product of mass and the rate of change of velocity, and the force predicted by this system neglects the mass during the observation. EMG may reflect the demand for muscle tissue, higher demand being associated with high force applied [69]. Another well-known method for obtaining body force is by using a force plate and foot plant combined with motion capture technologies $[32,33,41,76]$. However, this method only can obtain the body force for certain tasks. This shows that motion capture can help to approximate the body force applied from the body movement. Table 4 summarizes the contribution of kinetic and kinematic variables to the ergonomic risk assessment. 
Table 4. Summary for the contribution of the kinetic and kinematic variables to the ergonomic risk assessment.

\begin{tabular}{|c|c|}
\hline Variable & Contribution \\
\hline Velocity & $\begin{array}{l}\text { 1. Identify the suitable pace during working. } \\
\text { 2. Evaluate working movement and posture. } \\
\text { 3. Design workstation layout. }\end{array}$ \\
\hline Acceleration & $\begin{array}{l}\text { 1. Identify the angle of deviation for every joint. } \\
\text { 2. Determine the awkward posture. } \\
\text { 3. Recognize the repetitive movement during work. } \\
\text { 4. Assess the rate of change of velocity. } \\
\text { 5. Calculate the force exerted from work. }\end{array}$ \\
\hline Force & $\begin{array}{l}\text { 1. Determine the optimal load carried by worker. } \\
\text { 2. Calculate the momentum and work done. } \\
\text { 3. Evaluate the muscle activity. } \\
\text { 4. Evaluate the ergonomic risk. }\end{array}$ \\
\hline
\end{tabular}

\section{Conclusions}

This review has highlighted how current technology can analyze body motion using kinetic and kinematic variables with high accuracy. These variables, such as velocity, acceleration, and force, can give an added value in ergonomic risk assessment to achieve more reliable results. Evaluation of ergonomic risk assessment through quantitative data can avoid inconsistency and biased judgment in the assessment. The review was conducted to develop a complete method of ergonomic risk assessment, wherein the evaluation of kinetic and kinematic variables is very important. The more precise result achieved from the ergonomic risk assessment can increase accuracy in identifying the risk level of work tasks. As a result, the risk of work-related musculoskeletal disorder can be reduced. It can be postulated that the most recent studies that focus on the kinetic and kinematic variables used non-optical motion capture rather than optical motion capture. This is because optical motion capture is a very expensive and complicated experimental setup. However, the present review reveals that optical motion capture is more accurate than non-optical motion capture.

Author Contributions: Conceptualization: M.H.J. and M.S.H.; methodology: M.N.H.Y.; validation: M.H.J., M.S.H. and M.N.H.Y.; formal analysis, A.S.A.M.; investigation, N.Z.A.; resources, N.Z.A.; writing—original draft preparation, M.N.H.Y.; writing—review and editing, M.S.H.; visualization, M.H.J.; supervision, M.H.J. and A.S.A.M.; project administration, M.H.J.; funding acquisition, N.Z.A. All authors have read and agreed to the published version of the manuscript.

Funding: This research received no external funding.

Institutional Review Board Statement: Not applicable.

Informed Consent Statement: Not applicable.

Data Availability Statement: Not applicable.

Acknowledgments: Authors gratefully acknowledge to Ministry of Higher Education, Malaysia for providing the research grant (No.: 203/PTEKIND/6711821), as financial support.

Conflicts of Interest: The authors declare no conflict of interest.

\section{References}

1. Delice, E.K.; Can, G.F. A new approach for ergonomic risk assessment integrating KEMIRA, best worst and MCDM methods. Soft Comput. 2020, 24, 15093-15110. [CrossRef]

2. Samaei, S.E.; Tirgar, A.; Khanjani, N.; Mostafaee, M.; Hosseinabadi, M.B. Effect of personal risk factors on the prevalence rate of musculoskeletal disorders among workers of an Iranian rubber factory. Work 2017, 57, 547-553. [CrossRef] [PubMed] 
3. Penkala, S.; El-Debal, H.; Coxon, K. Work-related musculoskeletal problems related to laboratory training in university medical science students: A cross sectional survey. BMC Public Health 2018, 18, 1205. [CrossRef]

4. Álvarez, D.; Alvarez, J.C.; González, R.C.; López, A.M. Upper limb joint angle measurement in occupational health. Comput. Methods Biomech. Biomed. Eng. 2016, 19, 159-170. [CrossRef] [PubMed]

5. Antwi-Afari, M.F.; Li, H.; Edwards, D.J.; Pärn, E.A.; Seo, J.; Wong AY, L. Biomechanical analysis of risk factors for work-related musculoskeletal disorders during repetitive lifting task in construction workers. Autom. Constr. 2017, 83, 41-47. [CrossRef]

6. Hossain, M.D.; Aftab, A.; Hassan, M.; Imam, A.; Mahmud, I.; Chowdhury, I.A.; Kabir, R.I.; Sarker, M. Prevalence of work-related musculoskeletal disorders (WMSDs) and ergonomic risk assessment among readymade garment workers of Bangladesh: A cross sectional study. PLoS ONE 2018, 13, e0200122. [CrossRef] [PubMed]

7. Enez, K.; Nalbantoğlu, S.S. Comparison of ergonomic risk assessment outputs from OWAS and REBA in forestry timber harvesting. Int. J. Ind. Ergon. 2019, 70, 51-57. [CrossRef]

8. Isusi, I. Work-Related Musculoskeletal Disorders-Facts and Figures (Syntesis of 10 National Reports); European Agency for Safety and Health at Work: Luxembourg, 2020; pp. 1-80.

9. Pal, A.; Dhara, P. Evaluation of Work-Related Musculoskeletal Disorders and Postural Stress of Female "Jari" Workers. Indian J. Occup. Environ. Med. 2017, 21, 132.

10. Fletcher, S.R.; Johnson, T.L.; Thrower, J. A study to trial the use of inertial non-optical motion capture for ergonomic analysis of manufacturing work. Proc. Inst. Mech. Eng. Part B J. Eng. Manuf. 2018, 232, 90-98. [CrossRef]

11. Merino, G.; da Silva, L.; Mattos, D.; Guimarães, B.; Merino, E. Ergonomic evaluation of the musculoskeletal risks in a banana harvesting activity through qualitative and quantitative measures, with emphasis on motion capture (Xsens) and EMG. Int. J. Ind. Ergon. 2019, 69, 80-89. [CrossRef]

12. Petrosyan, T.; Dunoyan, A.; Mkrtchyan, H. Application of Motion Capture Systems in Ergonomic Analysis. Armen. J. Spec. Educ. 2020, 1, 107-117. [CrossRef]

13. Schmitz, A.; Ye, M.; Boggess, G.; Shapiro, R.; Yang, R.; Noehren, B. The measurement of in vivo joint angles during a squat using a single camera markerless motion capture system as compared to a marker-based system. Gait Posture 2015, 41, 694-698. [CrossRef] [PubMed]

14. Bortolini, M.; Faccio, M.; Gamberi, M.; Pilati, F. Motion Analysis System (MAS) for production and ergonomics assessment in the manufacturing processes. Comput. Ind. Eng. 2020, 139, 105485. [CrossRef]

15. Akhavian, R.; Behzadan, A.H. Smartphone-based construction workers' activity recognition and classification. Autom. Constr. 2016, 71, 198-209. [CrossRef]

16. Ide, D.; Tokcalar, O.; Gunduz, T. The effect of joint forces and torques on speed variation in automobile assembly lines. Work 2018, 61, 211-224. [CrossRef]

17. Abaeian, H.; Moselhi, O.; Al-hussein, M. System Dynamics Model Application for Ergonomic Assessment of Manual Material Handling Tasks; Modular and Offsite Construction: Edmonton, AB, Canada, 2016.

18. Bortolini, M.; Gamberi, M.; Pilati, F.; Regattieri, A. Automatic assessment of the ergonomic risk for manual manufacturing and assembly activities through optical motion capture technology. Procedia CIRP 2018, 72, 81-86. [CrossRef]

19. Kaharuddin, M.Z.; Khairu Razak, S.B.; Kushairi, M.I.; Abd Rahman, M.S.; An, W.C.; Ngali, Z.; Siswanto, W.A.; Salleh, S.M.; Yusup, E.M. Biomechanics Analysis of Combat Sport (Silat) by Using Motion Capture System. IOP Conf. Ser. Mater. Sci. Eng. 2017, 166, 012028. [CrossRef]

20. Ray, P.K.; Parida, R.; Sarkar, S. Ergonomic Analysis of Construction Jobs in India: A Biomechanical Modelling Approach. Procedia Manuf. 2015, 3, 4606-4612. [CrossRef]

21. Agethen, P.; Otto, M.; Mengel, S.; Rukzio, E. Using Marker-less Motion Capture Systems for Walk Path Analysis in Paced Assembly Flow Lines. Procedia CIRP 2016, 54, 152-157. [CrossRef]

22. Kim, J.H.; Hwang, J.; Jung, M.; Mo, S. The Kinematic Evaluation of Shoulder and Elbow Joints for Different Walking Speeds. Int. J. Eng. Technol. 2019, 11, 169-172. [CrossRef]

23. Soh, A.A.S.A.; Jafri, M.Z.; Azraai, N.Z. Power estimation of martial arts movement with different physical, mood, and behavior using motion capture camera. In Optics for Arts, Architecture, and Archaeology VI; International Society for Optics and Photonics: Bellingham, WA, USA, 2017; Volume 10331, p. 103310X.

24. Maurice, P.; Malaisé, A.; Amiot, C.; Paris, N.; Richard, G.J.; Rochel, O.; Ivaldi, S. Human movement and ergonomics: An industry-oriented dataset for collaborative robotics. Int. J. Robot. Res. 2019, 38, 1529-1537. [CrossRef]

25. Eldar, R.; Fisher-Gewirtzman, D. Ergonomic design visualization mapping-developing an assistive model for design activities. Int. J. Ind. Ergon. 2019, 74, 102859. [CrossRef]

26. Antwi-Afari, M.F.; Li, H.; Luo, X.E.; Edwards, D.J.; Owusu-Manu, D.; Darko, A. Overexertion-related construction workers' activity recognition and ergonomic risk assessment based on wearable insole pressure system. In Proceedings of the West Africa Built Environment Research Conference, Accra, Ghana, 5-7 August 2019; pp. 788-796.

27. Scalise, L.; Paone, N. Pressure sensor matrix for indirect measurement of grip and push forces exerted on a handle. Measurement J. Int. Meas. Confed. 2015, 73, 419-428. [CrossRef]

28. Nath, N.D.; Akhavian, R.; Behzadan, A.H. Ergonomic analysis of construction worker's body postures using wearable mobile sensors. Appl. Ergon. 2017, 62, 107-117. [CrossRef] 
29. Jahanbanifar, S.; Akhavian, R. Evaluation of wearable sensors to quantify construction workers muscle force: An ergonomic analysis. In Proceedings of the Winter Simulation Conference, Gothenburg, Sweeden, 9-12 December 2018; pp. 3921-3929.

30. Waddell, M.L.; Amazeen, E.L. Lift speed moderates the effects of muscle activity on perceived heaviness. Q. J. Exp. Psychol. 2016, 71, 2174-2185. [CrossRef] [PubMed]

31. Fleron, M.K.; Ubbesen, N.C.H.; Battistella, F.; Dejtiar, D.L.; Oliveira, A.S. Accuracy between optical and inertial motion capture systems for assessing trunk speed during preferred gait and transition periods. Sports Biomech. 2019, 18, 366-377. [CrossRef]

32. White, S.C.; Hostler, D. The effect of firefighter protective garments, self-contained breathing apparatus and exertion in the heat on postural sway. Ergonomics 2017, 60, 1137-1145. [CrossRef]

33. Nelson-Wong, E.; Gallagher, K.; Johnson, E.; Antonioli, C.; Ferguson, A.; Harris, S.; Johnson, H.; Miller, J.B. Increasing standing tolerance in office workers with standing-induced back pain. Ergonomics 2020, 63, 804-817. [CrossRef]

34. Jun, D.; Johnston, V.; McPhail, S.M.; O'Leary, S. Are Measures of Postural Behavior Using Motion Sensors in Seated Office Workers Reliable? Hum. Factors 2019, 61, 1141-1161. [CrossRef]

35. Aurand, A.M.; Dufour, J.S.; Marras, W.S. Accuracy map of an optical motion capture system with 42 or 21 cameras in a large measurement volume. J. Biomech. 2017, 58, 237-240. [CrossRef] [PubMed]

36. Arendra, A.; Akhmad, S.; Lumintu, I. Working tool redesign to reduce ergonomic risk of salt evaporation field workers based on RULA and REBA assessments using esMOCA Instrument. J. Phys. Conf. Ser. 2020, 1477, 022034. [CrossRef]

37. Dhyani, M.; Roll, S.C.; Gilbertson, M.W.; Orlowski, M.; Anvari, A.; Li, Q.; Anthony, B.; Samir, A.E. A pilot study to precisely quantify forces applied by sonographers while scanning: A step toward reducing ergonomic injury. Work 2017, 58, 241-247. [CrossRef] [PubMed]

38. Yu, K.; Barmaki, R.; Unberath, M.; Mears, A.; Brey, J.; Hwan, T.; Chung, M.D.; Navab, N. On the Accuracy of Low-Cost Motion Capture Systems for Range of Motion Measurements; SPIE Medical Imaging: Houston, TX, USA, 2018; p. 10579.

39. Patrizi, A.; Pennestrì, E.; Valentini, P.P. Comparison between low-cost marker-less and high-end marker-based motion capture systems for the computer-aided assessment of working ergonomics. Ergonomics 2016, 59, 155-162. [CrossRef] [PubMed]

40. Perrott, M.A.; Pizzari, T.; Cook, J.; McClelland, J.A. Comparison of lower limb and trunk kinematics between markerless and marker-based motion capture systems. Gait Posture 2017, 52, 57-61. [CrossRef]

41. Karatsidis, A.; Bellusci, G.; Schepers, H.M.; de Zee, M.; Andersen, M.S.; Veltink, P.H. Estimation of ground reaction forces and moments during gait using only inertial motion capture. Sensors 2017, 17, 75. [CrossRef] [PubMed]

42. Humadi, A.; Nazarahari, M.; Ahmad, R.; Rouhani, H. In-field instrumented ergonomic risk assessment: Inertial measurement units versus Kinect V2. Int. J. Ind. Ergon. 2021, 84, 103147. [CrossRef]

43. Brunner, O.; Mertens, A.; Nitsch, V.; Brandl, C. Accuracy of a Markerless Motion Capture System for Postural Ergonomic Risk Assessment in Occupational Practice. Int. J. Occup. Saf. Ergon. 2021, in press. [CrossRef]

44. Huang, C.; Kim, W.; Zhang, Y.; Xiong, S. Development and Validation of a Wearable Inertial Sensors-Based Automated System for Assessing Work-Related Musculoskeletal Disorders in the Workspace. Int. J. Environ. Res. Public Health 2020, 17, 6050. [CrossRef] [PubMed]

45. Abedi, M.; Ghanbary, A.; Habibi, E.; Palyzban, F.; Ghasemi, H.; Hasani, A.A. Back Compressive Force (BCF) assessment using UTAH method in manual handling tasks among workers of a chemical manufacturing company. J. Occup. Health Epidemiol. 2018, 7, 222-226. [CrossRef]

46. Kamat, S.R.; Zula, N.M.; Rayme, N.S.; Shamsuddin, S.; Husain, K. The ergonomics body posture on repetitive and heavy lifting activities of workers in aerospace manufacturing warehouse. IOP Conf. Ser. Mater. Sci. Eng. 2017, 210, 012079. [CrossRef]

47. Namnik, N.; Negahban, H.; Salehi, R.; Shafizadeh, R.; Tabib, M.S. Validity and reliability of Persian version of the Specific Nordic questionnaire in Iranian industrial workers. Work 2016, 54, 35-41. [CrossRef] [PubMed]

48. Kahraman, T.; Genç, A.; Göz, E. The Nordic Musculoskeletal Questionnaire: Cross-cultural adaptation into Turkish assessing its psychometric properties. Disabil. Rehabil. 2016, 38, 2153-2160. [CrossRef]

49. Cremasco, M.M.; Giustetto, A.; Caffaro, F.; Colantoni, A.; Cavallo, E.; Grigolato, S. Risk assessment for musculoskeletal disorders in forestry: A comparison between RULA and REBA in the manual feeding of a wood-chipper. Int. J. Environ. Res. Public Health 2019, 16, 793. [CrossRef] [PubMed]

50. Bidiawati, J.R.; Suryani, E. Improving the Work Position of Worker's Based on Quick Exposure Check Method to Reduce the Risk of Work-Related Musculoskeletal Disorders. Procedia Manuf. 2015, 4, 496-503. [CrossRef]

51. Gómez-Galán, M.; Callejón-Ferre, Á.J.; Pérez-Alonso, J.; Díaz-Pérez, M.; Carrillo-Castrillo, J.A. Musculoskeletal risks: RULA bibliometric review. Int. J. Environ. Res. Public Health 2020, 17, 4354. [CrossRef] [PubMed]

52. Hita-Gutiérrez, M.; Gómez-Galán, M.; Díaz-Pérez, M.; Callejón-Ferre, Á.J. An overview of reba method applications in the world. Int. J. Environ. Res. Public Health 2020, 17, 2635. [CrossRef]

53. Abd Rahman, M.K.; Shahriman, A.B.; Desa, H.; Daud, R.; Razlan, Z.M.; Wan, K.; Cheng, E.M.; Afendi, M. Comparative Study of Rapid Upper Limb Assessment (RULA) and Rapid Entire Body Assessment (REBA) between Conventional and Machine Assisted Napier Grass Harvest Works. Appl. Mech. Mater. 2015, 786, 275-280. [CrossRef]

54. Plantard, P.; Auvinet, E.; Le Pierres, A.S.; Multon, F. Pose estimation with a kinect for ergonomic studies: Evaluation of the accuracy using a virtual mannequin. Sensors 2015, 15, 1785-1803. [CrossRef]

55. Lowe, B.D.; Dempsey, P.G.; Jones, E.M. Ergonomics assessment methods used by ergonomics professionals. Appl. Ergon. 2019, 81, 102882. [CrossRef] 
56. Zare, M.; Biau, S.; Brunet, R.; Roquelaure, Y. Comparison of three methods for evaluation of work postures in a truck assembly plant. Ergonomics 2017, 60, 1551-1563. [CrossRef]

57. Kim, W.; Sung, J.; Saakes, D.; Huang, C.; Xiong, S. Ergonomic postural assessment using a new open-source human pose estimation technology (OpenPose). Int. J. Ind. Ergon. 2021, 84, 103164. [CrossRef]

58. Ansari, N.A.; Sheikh, D.M.J. Evaluation of work Posture by RULA and REBA: A Case Study. IOSR J. Mech. Civ. Eng. 2014, 11, 18-23. [CrossRef]

59. Rizkya, I.; Syahputri, K.; Sari, R.M.; Siregar, I. Evaluation of work posture and quantification of fatigue by Rapid Entire Body Assessment (REBA). IOP Conf. Ser. Mater. Sci. Eng. 2018, 309, 012051. [CrossRef]

60. Choi, K.H.; Kim, D.M.; Cho, M.U.; Park, C.W.; Kim, S.Y.; Kim, M.J.; Kong, Y.K. Application of aula risk assessment tool by comparison with other ergonomic risk assessment tools. Int. J. Environ. Res. Public Health 2020, 17, 6479. [CrossRef]

61. Jones, T.; Kumar, S. Comparison of ergonomic risk assessment output in four sawmill jobs. Int. J. Occup. Saf. Ergon. 2010, 16, 105-111. [CrossRef] [PubMed]

62. Kim, T.; Xiong, S. Comparison of seven fall risk assessment tools in community-dwelling Korean older women. Ergonomics 2017, 60, 421-429. [CrossRef] [PubMed]

63. Valero, E.; Sivanathan, A.; Bosché, F.; Abdel-Wahab, M. Musculoskeletal disorders in construction: A review and a novel system for activity tracking with body area network. Appl. Ergon. 2016, 54, 120-130. [CrossRef] [PubMed]

64. Lee, W.; Seto, E.; Lin, K.Y.; Migliaccio, G.C. An evaluation of wearable sensors and their placements for analyzing construction worker's trunk posture in laboratory conditions. Appl. Ergon. 2017, 65, 424-436. [CrossRef]

65. Plantard, P.; Shum, H.P.; Le Pierres, A.S.; Multon, F. Validation of an ergonomic assessment method using Kinect data in real workplace conditions. Appl. Ergon. 2017, 65, 562-569. [CrossRef]

66. Brandl, C.; Mertens, A.; Schlick, C.M. Effect of sampling interval on the reliability of ergonomic analysis using the Ovako working posture analysing system (OWAS). Int. J. Ind. Ergon. 2017, 57, 68-73. [CrossRef]

67. Soh, A.A.; Jafri, M.Z.; Azraai, N.Z. Study of human body: Kinematics and kinetics of a martial arts (Silat) performers using 3D-motion capture. AIP Conf. Proc. 2015, 1657, 040009.

68. Swaminathan, R.; Williams, J.M.; Jones, M.D.; Theobald, P.S. The prediction of neck extensor force using surface electromyography. J. Back Musculoskelet. Rehabil. 2016, 29, 279-285. [CrossRef]

69. Caputo, F.; Amato, E.D.; Spada, S.; Sessa, F.; Losardo, M. Upper Body Motion Tracking System with Inertial Sensors for Ergonomic Issues in Industrial Environments. Adv. Phys. Ergon. Hum. Factors 2016, 489, 801-812.

70. Lavender, S.A.; Sommerich, C.M.; Bigelow, S.; Weston, E.B.; Seagren, K.; Pay, N.A.; Sillars, D.; Ramachandran, V.; Sun, C.; Xu, Y.; et al. A biomechanical evaluation of potential ergonomic solutions for use by firefighter and EMS providers when lifting heavy patients in their homes. Appl. Ergon. 2020, 82, 102910. [CrossRef]

71. Dickerson, C.R.; Alenabi, T.; Martin, B.J.; Chaffin, D.B. Shoulder muscular activity in individuals with low back pain and spinal cord injury during seated manual load transfer tasks. Ergonomics 2018, 61, 1094-1101. [CrossRef] [PubMed]

72. Greenland, K.O.; Merryweather, A.S.; Bloswick, D.S. The effect of lifting speed on cumulative and peak biomechanical loading for symmetric lifting tasks. Saf. Health Work 2013, 4, 105-110. [CrossRef] [PubMed]

73. Yoon, J.; Shiekhzadeh, A.; Nordin, M. The effect of load weight vs. pace on muscle recruitment during lifting. Appl. Ergon. 2012, 43, 1044-1050. [CrossRef]

74. Wang, T.J. A study on utilizing 3D motion-capture analysis to assist in Chinese opera teaching. Res. Danc. Educ. 2020. [CrossRef]

75. Chen, J.; Qiu, J.; Ahn, C. Construction worker's awkward posture recognition through supervised motion tensor decomposition. Autom. Constr. 2017, 77, 67-81. [CrossRef]

76. Wardoyo, S.; Hutajulu, P.T.; Togibasa, O. A Development of Force Plate for Biomechanics Analysis of Standing and Walking. J. Phys. Conf. Ser. 2016, 739, 012118. [CrossRef] 